\section{LORAN L. GOULDEN, ALBERTA NATURALIST}

\section{by MARTIN K. McNICHOLL*}

The tragic death of Loran L. oulden in a plane crash on Riddle untain, B.C. on August I, 1974 , ought to a close a short, but nificant chapter in the history of tural history in Alberta. Loran was a fessional photographer of outstanig merit, but devoted most of his are time in his last 3 years to bird idy. He became a professional turalist shortly before his death, en he joined an environmental conting firm in Edmonton.

Loran's contribution to nature study Alberta, and especially in Edmon1, cannot be overstated. He initiated edited regular faunal reports for northern half of Alberta, blishing these in the Edmonton turalist. For these reports he coerated with the Provincial Museum Archives of Alberta in designing Alberta Animal Record Card. ese cards and reports are a conuing memorial to Loran's memory. ran also initiated an extensive series workshop-style classes in various pects of nature, co-sponsored by the monton Natural History Club and Provincial Museum. He personally ducted the most popular and timensuming of these: birds of Alberta. January, 1973, Loran was elected esident of the Edmonton Natural story Club, a post which he still held his death. His contributions to the ab far exceeded those expected of a esident. Loran was also a Director the Federation of Alberta turalists and Chairman of FAN's dangered Species Committee.

His more academic pursuits inided the running of a bird study plot Elk Island National Park for the nter and breeding birds censuses blished annually by American Birds,

ept. of Zoology,

niversity of Alberta,

dmonton, Alberta.

$6 \mathrm{G} 2 \mathrm{E} 1$ contribution of several maps to a book on the early winter distribution of birds in North America, and conducting a route for the Breeding Bird Survey of the U.S. Fish and Wildlife Service and Canadian Wildlife Service. He published articles in the Alberta Naturalist, Blue Jay, and Auk, as well as the Edmonton Naturalist, for which he was faunal editor. He also published a book review in the Canadian FieldNaturalist and. was on the editorial board of Western Birds.

A much more complete account of Loran's brief, but productive career is detailed in an article by this writer in the first 1975 issue of the Alberta Naturalist.

\section{III 其a Arg Ana}

From the 11-page mimeographed Blue Jay of January-February-March, 1945, come the following notes:

Some young members of the Yorkton N.H.S. counted muskrat houses for Ducks Unlimited on November 9, 1944. There were 353 houses on Upper Rousay Lake (169 the year before) and 223 on Lower Rousay (compared to 25 in 1943) ... Don Knox estimated that 5,000-6,000 ducks were killed on November 15 at Clair apparently as they attempted to land (at night) in a stubble field covered with hoar frost under a sky of thick fog and smoke... Bounties of 5 cents each were paid on 1,092 woodchucks by the RM around Tisdale in 1944 ... Lindsay and Bill Wotherspoon of Hyas caught a chickadee in 1937 that they had banded 5 years earlier... In 1942 Arthur Ward of Burnham recaught two robins that he had banded in 1940 and 1941 .

Twenty-eight people reported 33 species of birds in 12 Saskatchewan Christmas Counts in 1944. The 